\title{
Assessment of metal pollution using enrichment factor (EF) and pollution load index (PLI) in sediments of selected terengganu rivers, Malaysia
}

\author{
Nor Sayzwani Sukri a, ${ }^{*}$, Siti Amirah Aspin a, Nurul Liyana Kamarulzaman a , Nurul Fazlina Jaafar a, \\ Rozidaini Mohd Ghazi a, Nor Shahida Shafiee @ Ismail a, Siti Hajar Yaacob a, Farah Khaliz Kedria, \\ Mohamad Pauzi Zakaria b, a,
}

a Faculty of Earth Science, University of Malaysia Kelantan

b Bachok Marine Research Station, Institute of Ocean and Earth Science, University of Malaya

* Corresponding author: sayzwani@umk.edu.my

Article history

Submitted 27 February 2018

Revised 28 March 2018

Accepted 30 April 2018

Published Online 4 June 2018

\begin{abstract}
Anthropogenic activities that happen in Terengganu River were contributed to sediment pollution at that area. The sediment pollution occurred when sediment are additional influenced with chemical adsorption between the metals, grain size, and organic matter. Thus, this study was conducted to assess the metal pollution using Enrichment Factor (EF) and Pollution Load Index (PLI) and compared with the previous study. A total of 15 sediment samples were collected from 5 different rives and metal concentration were analyzed using flame Atomic Absorption Spectrometer (ASS). The metal concentration ranged as followed: $\mathrm{Cr}(0.48-12.80 \mathrm{mg} / \mathrm{kg}), \mathrm{Cu}(0.38-15.20 \mathrm{mg} / \mathrm{kg}), \mathrm{Mg}$ $(202.00-2769.00 \mathrm{mg} / \mathrm{kg}), \mathrm{K}(63.36-1730.00 \mathrm{mg} / \mathrm{kg}), \mathrm{Mn}(4.27-33.70 \mathrm{mg} / \mathrm{kg}), \mathrm{Zn}(2.05-31.30 \mathrm{mg} / \mathrm{kg})$ and $\mathrm{Cl}$ (141.00-584.00 mg/kg) respectively. Enrichment Factor (EF) and Pollution Load Index (PLI) were used as a pollution indicator to access the sediment pollution in selected Terengganu Rivers. The mean Enrichment Factor (EF) value indicated in decrease order $\mathrm{Cl}(34.70)>\mathrm{Zn}(23.44)>\mathrm{Cu}$ $(10.37)>\mathrm{Cr}(1.95)>\mathrm{K}(1.58)>\mathrm{Mg}(1.16)>\mathrm{Mn}(0.87)$. Meanwhile, Pollution Load Index (PLI) value showed below than 1 in all sampling stations. When compared with previous study, $\mathrm{Mg}$ and $\mathrm{Cl}$ metals need to take further action due to dramatically increased within seven years. The output from this study will be useful for environmental management at Terengganu Rivers.
\end{abstract}

Keywords: Enrichment Factor (EF); Pollution Load Index (PLI); sediment

\section{INTRODUCTION}

Environmental pollution is the presence of a pollutant in the environment such as air, water and soil, which may be poisonous or toxic and can give effect to living things in the polluted environment. Since they cannot be degraded or destroyed, heavy metals occur as natural constituents of the earth crust, and are persistent environmental contaminants.

A mixture of several components, including different species of mineral and organic debris is sediment. Heavy metals released into the environment is one of the main basin is represented by sediments (Alkarkhi et al., 2009). For aquatic organisms, sediment is a habitat and major nutrient source. Sediments reflect the current quality of the system as well as give information on the impact of pollution sources. Therefore, it needs a technology to investigate heavy metal in water bodies.

Sediments reflect the current quality of the system as well as provide information on the impact of pollution sources (Szalinska $e t$ al., 2006). The interaction between water, sediment and aquatic organisms can specially refer to heavy metal in sediment.

Sediments in aquatic environments serve as a pool that can retain metals or release metals to the water column by various processes of remobilization. The concentrations of metals in sediments can be sensitive indicators of contaminants in aquatic systems (Barakat et al., 2012). Every contamination heavy metal can give an effect to human and environmental

Sediments are combination of several components of mineral species such as organic debris and its act as the accumulation of metals in the environment. It also used to assess the impact of anthropogenic activities to the aquatic environment (Zulkifli et al., 2015).

In Malaysia, there are three large basins in East Cost of Peninsular Malaysia namely Terengganu River basin, Kelantan River basin and Pahang River basin. These three main river basins are influenced by the heavy rainfall from Northeast monsoon. In Terengganu River basin, the total catchment area are respectively $5000 \mathrm{~km}^{2}$ and the length is $100 \mathrm{~km}$ (Sultan \& Shazili, 2010).

The Terengganu River Basin received and carries different kinds of liquid and solid wastes from agricultural and urban development through socio-economical activities. Moreover, these activities contributed pollution to the river where by generated based on agricultural plantation (rubber and palm oil), commercial industries, mining activities, transportation, petro-chemical industries and 
domestic waste (Hasrizal, Kamaruzzaman, Sakri, Ong, \& Azhar, 2009; Suratman, Sailan, Hee, Bedurus, \& Latif, 2015).

Hence, the aims of this study are to assess the metal pollution using Enrichment Factor (EF) and Pollution Load Index (PLI) and compared with the previous study sfecifically at Sungai Kerteh, Sungai Paka, Sungai Terengganu, Sungai Dungun and Sungai Besut.

\section{LITERATURE REVIEW}

Sediment was categorizing as nonpoint source pollutants because it come from various sources and being introduced to the river through the surface runoff. When human activities occurred near the river and produced potential source of heavy metal such as agricultural runoff and oil spill from the ships and boats, the soil particles that are transported by surface water movement can cause sediment pollution (Hangsleben \& Suh, 2006).

The sediment pollution occurred when sediment are additional influenced with chemical adsorption between the metals, grain size, and organic matter (Aprile \& Bouvy, 2008). The natural source of heavy metal comes from the earth and it's become a concern when higher concentration of the heavy metal is occurred in the environment. Natural sources commonly comes from the weathering of soil and rock, erosion, wildlife fire, and volcanic eruptions activities and being released naturally into the rivers (Ren et al., 2015).

Sediments in the river are significant sinks for various pollutants such as heavy metal pollutions. In spite of being place for sink a pollutant, sediment play a big role as a secondary source for identifying a contaminant (Yang, Zhu, \& Liu, 2011). Therefore, anthropogenic activity can be attestation as the commit to pollution of heavy metal in the sediment.

Anthropogenic source comes from the human activities such as mining, industrial effluent, agricultural runoff, residential waste and vehicle emission (Rajeswari \& Sailaja, 2014). As for the source that cause heavy metal adsorption in the sediment is from the vehicle emission such as boat and ship, agriculture activity near the river, and the residential effluent from unmanaged drainage.

Despite of that, the seasonal wind patterns influence with nature of the local topography determines rainfall patterns in Malaysia. During the northeast monsoon, the exposed areas such as the east coast of Peninsular Malaysia facing with heavy rain. On the other hand, rural areas or areas protected mountain range is relatively free from this influence. For states in the east coast of Peninsular Malaysia, November, December and January are the months with maximum rainfall, while June and July are the driest months in most states in most states (Malaysian Metrological Department (MMD), 2016).

Generally, during the last phase of Northeast Monsoon the wind began to blow from all directions and there are some areas which have received less rainfall due to phenomenon of El Nino. This is important to realize at this current situation, the state of Terengganu received limited rain which is over $60 \%$ below the average total rainfall of about 50mm ((MMD), 2016). The El Nino phenomenons give adverse effect to river ecosystem and influence the river to dry. On the contrary to the northeast monsoon, (Rajan et al., 2012) proved that the degree of pollutant in the water is higher after the rain fall season. However, at this current time during the Northeast Monsoon including the El Nino phenomenon in 2016, the pollutions in the river sediment are expected to be lower than before.

\section{METHODOLOGY}

\section{Sampling area}

Table 1 Global positioning system (GPS) and description of sampling locations.

\begin{tabular}{|c|c|c|c|}
\hline Station & Latitude & Longitude & Description \\
\hline SK 1 & N 04³1'01.7' & E 10327'09.1" & Nearby fisheries area \\
\hline SK 2 & N 4³1'58.02" & E $103^{\circ} 26^{\prime} 7.42^{\prime \prime}$ & $\begin{array}{l}\text { Water way discharge } \\
\text { from airport }\end{array}$ \\
\hline SK 3 & N 04울.589' & E $103^{\circ} 26.485^{\prime}$ & Petroleum plantation \\
\hline SP 1 & N 438'28.10" & E $103^{\circ} 26^{\prime} 13.41^{\prime \prime}$ & Aquaculture activities \\
\hline SP 2 & 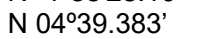 & E $103^{\circ} 23.992^{\prime}$ & Petroleum plantation \\
\hline SP 3 & 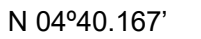 & E $103^{\circ} 24.068^{\prime}$ & Aquaculture activities \\
\hline SD 1 & N 446'49.40" & E 10325'30.99" & Jetty \\
\hline SD 2 & N 446'47.81" & E $103^{\circ} 25^{\prime} 23.56^{\prime \prime}$ & Boat parking \\
\hline SD 3 & N 44ㅇ'50.58" & E $103^{\circ} 25^{\prime} 17.22^{\prime \prime}$ & $\begin{array}{l}\text { Nearby to road } \\
\text { bridge }\end{array}$ \\
\hline ST 1 & N 5¹9'46.58" & E $103^{\circ} 7^{\prime} 53.06^{\prime \prime}$ & Jetty \\
\hline ST 2 & N 5¹9'23.77" & E $103^{\circ} 7^{\prime} 28.79^{\prime \prime}$ & Road bridge \\
\hline ST 3 & N 5¹9'9.46" & E $103^{\circ} 7^{\prime} 8.86^{\prime \prime}$ & Nearby to bushes \\
\hline SB 1 & N 549'49.28" & E $102^{\circ} 33^{\prime} 32.41^{\prime \prime}$ & Jetty \\
\hline SB 2 & N 548'52.10" & E 102॰33'33.99" & Aquaculture activities \\
\hline SB 3 & N 548'5.23" & E 102॰33'29.68" & Residential areas \\
\hline
\end{tabular}

*SK=Sungai Kerteh; $\mathrm{SD}=$ Sungai Dungun; $\mathrm{ST}=$ Sungai

Terengganu;SB=Sungai Besut

\section{Sampling collection and sampling treatment}

Approximately $4 \mathrm{~cm}$ of sediment were collected from five different rivers which are Sungai Kerteh, Sungai Paka, Sungai Dungun, Sungai Terengganu and Sungai Besut using Ekman grab sampler. About 3 sampling points were selected at each river. Sampling points were geo-located using geographical positioning system (GPS) to ensure consistency. The sampling stations were selected based on the description below (Table 1). The sediment was kept into clean polythene bag until the further analysis. All samples securely labeled with a unique sample number at the sampling site.

Sediment samples were dried in the oven at $80^{\circ} \mathrm{C}$ for 48 hours and postal slaved by passing through $600 \mu \mathrm{m}$ mesh. 0.5 gram of each sample was weighed carefully and $10 \mathrm{~mL}$ of concentrated nitric acid (HNO3), $10 \mathrm{~mL}$ of hydrochloric acid (HCL) and $10 \mathrm{~mL}$ of distilled water was added to each sample. The sample, then, was heated up on hot plate. The sample was heat until it reduces to $25 \mathrm{~mL}$ or until clear solution obtained. Next, cool the solution. The suspension was filtered (Whatman filter Merck, $0.45 \mu \mathrm{m}$ ) and transfer to $50 \mathrm{~mL}$ volumetric flask. Then, the filtrate was diluted by distilled water and transfer to plastic bottle. For preservation, the already digest sample were preserved under temperature $4{ }^{\circ} \mathrm{C}$ in refrigerator and the conical flask were covered using parafilm.

The prepared samples were analyzed by an atomic absorption spectrometry (AAS). Seven metals were analyzed in sediment sample which are chromium $(\mathrm{Cr})$, cupper $(\mathrm{Cu})$, magnesium $(\mathrm{Mg})$, potassium $(\mathrm{K})$, manganese $(\mathrm{Mn})$, zinc $(\mathrm{Zn})$ and chlorine $(\mathrm{Cl})$

\section{Assessment of metal contamination}

Enrichment factor (EF) is used to know the origin of the elements found in river sediment (Qingjie et al., 2008). The calculated EF value from the analysed heavy metals is also to evaluate whether the source of heavy metals was from natural or anthropogenic source (Parizanganeh, Bijnavand, Zamani, \& Hajabolfath, 2012). Besides, Enrichment Factor also use as an indicator of pollution (Adamo et al., 2005) using the following formula:

$$
E F=(X F e) \text { sample } /(X F e) \text { background }
$$

Where $(\mathrm{XFe})$ sample is a metal to Fe ratio of examined element and $(\mathrm{XFe})$ background is a background value of metal to Fe ratio. In this study, Iron was chosen as reference element. The categories of EF are listed in the Table 2. 


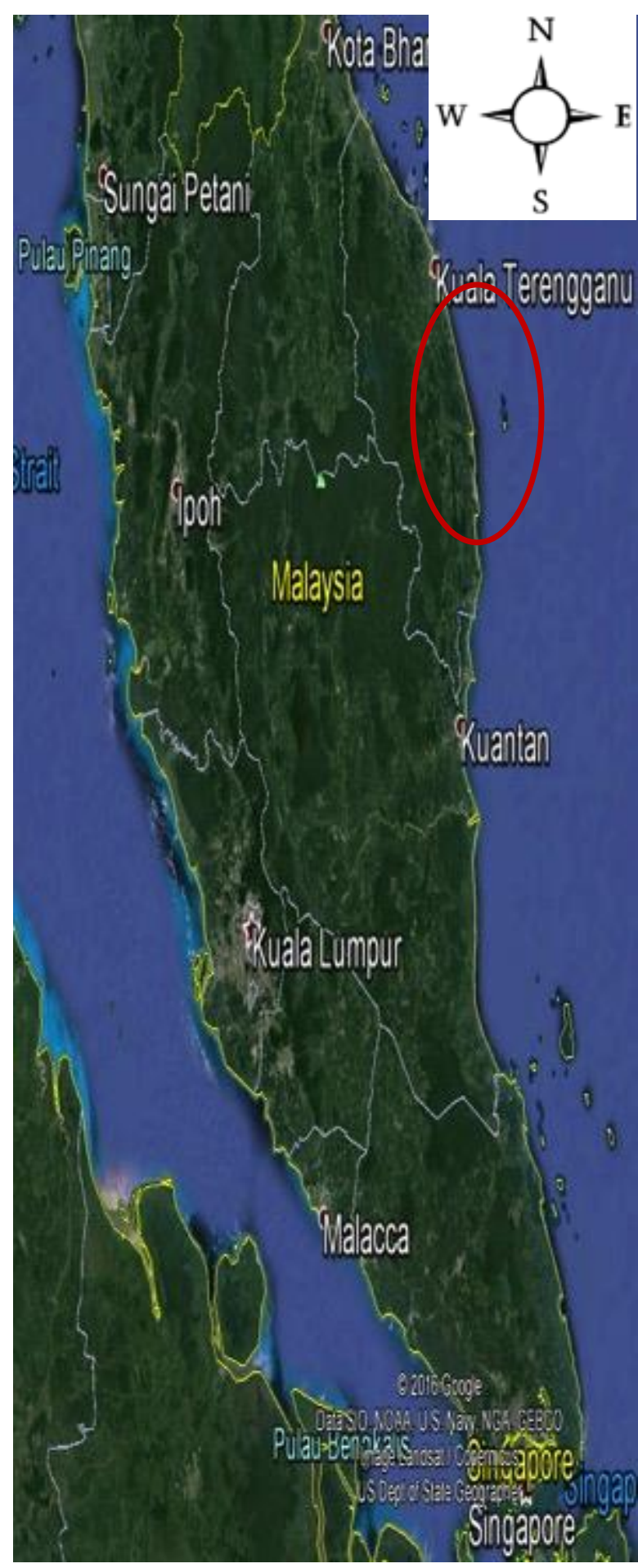

Source: Google Earth

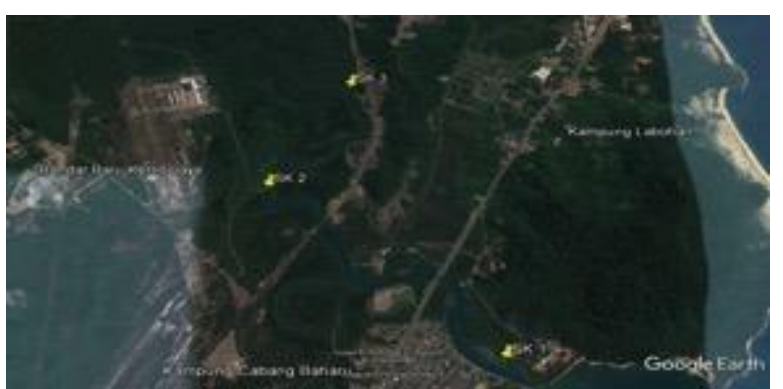

Sungai Kerteh

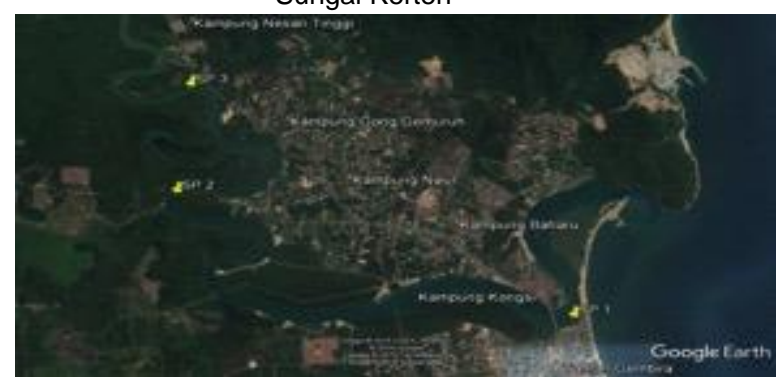

Sungai Paka

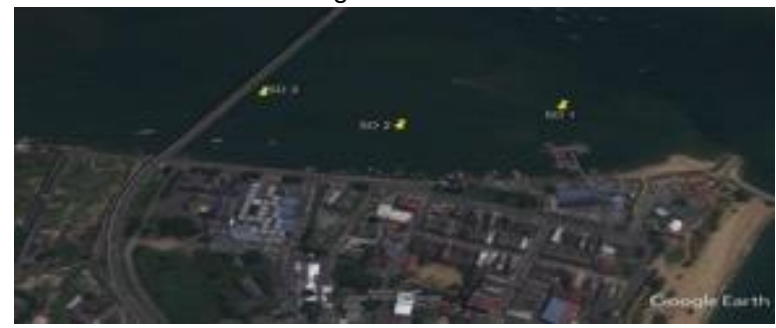

Sungai Dungun

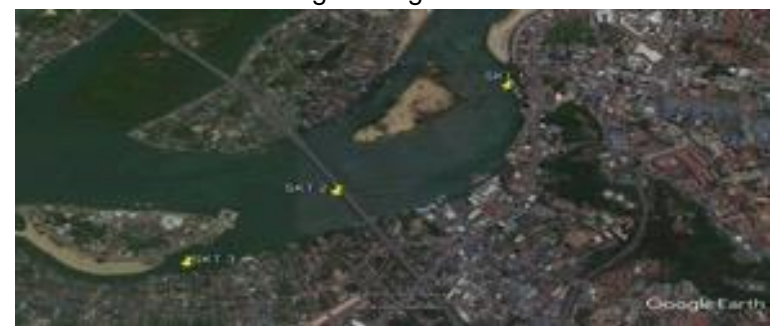

Sungai Terengganu

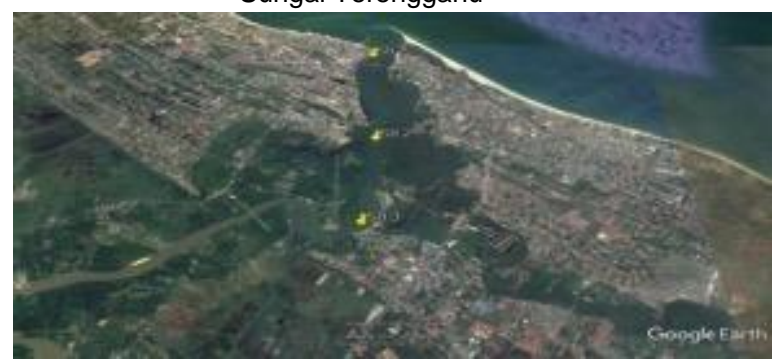

Sungai Besut

Fig. 1 Sampling stations of sediment samples.

Pollution load index (PLI) is one of the parameter that can be used to estimate the metal contamination status and the necessary action that should be taken (Likuku, Mmolawa, \& Gaboutloeloe, 2013). In other words, pollution provides simple but comparative means for assessing

$$
P L I=\left(\begin{array}{lllll}
C F_{1} & X & C F_{2} & X \ldots \ldots \ldots X & \ldots
\end{array} F_{n}\right)^{\wedge(1 / N)}
$$

Where $\mathrm{CF}_{\text {metals }}$ was the ratio between concentration of each metal with the background values in sediment as stated in equation (3). a site quality . Tomlinson et al. (1980) has proposed how to calculate the pollution load index using the same thing but different as shown in equation (2).

$$
C F=\left[C_{\text {metal }}\right] /\left[C_{\text {background }}\right]
$$

The $\mathrm{CF}$ and EF classification are listed in the Table 3. 
Table 2 Enrichment factor categories.

\begin{tabular}{cc}
\hline Enrichment factor (EF) & Enrichment factor (EF) Categories \\
\hline$E F<2$ & Deficiency to minimal enrichment \\
$2 \leq \mathrm{EF}<5$ & Moderate enrichment \\
$5 \leq \mathrm{EF}<20$ & Significant enrichment \\
$20 \leq \mathrm{EF}<40$ & Very high enrichment \\
$\mathrm{EF} \geq 40$ & Extremely high enrichment \\
\hline
\end{tabular}

(Source: Salah et al., 2012)

\section{RESULT AND DISCUSSION}

From this study, the range of metal concentration at each sampling location are 0.48 to $12.80 \mathrm{mg} / \mathrm{kg}$ for $\mathrm{Cr}, 0.38$ to $15.20 \mathrm{mg} / \mathrm{kg}$ for $\mathrm{Cu}$,
202.00 to $2769.00 \mathrm{mg} / \mathrm{kg}$ for $\mathrm{Mg}, 63.36$ to $1730.00 \mathrm{mg} / \mathrm{kg}$ for $\mathrm{K}, 4.27$ to $33.70 \mathrm{mg} / \mathrm{kg}$ for $\mathrm{Mn}, 2.05$ to $31.30 \mathrm{mg} / \mathrm{kg}$ for $\mathrm{Zn}$ and 141.00 to $584.00 \mathrm{mg} / \mathrm{kg}$ for $\mathrm{Cl}$ (Table 4) . Based on the mean values, the metals follow the decreasing order as followed; $\mathrm{Mg}>\mathrm{K}>\mathrm{Cl}>\mathrm{Mn}>\mathrm{Zn}$ $>\mathrm{Cu}>\mathrm{Cr}$. . The data shows, elements of $\mathrm{Mg}, \mathrm{K}$ and $\mathrm{Cl}$ are the dominant element that found in this study areas. Whereas, $\mathrm{Cu}$ and $\mathrm{Cr}$ are the lowest concentration found in sediment samples. The $\mathrm{Mg}$ and $\mathrm{Cl}$ metals shows higher concentration compared with the previous study in Malaysia (Table 5) especially when compared with Sultan et al., 2010 that already studied in Sungai Terengganu seven years ago. The massive developed that happened in Terengganu rivers influenced the concentration of metals in the sediment.

Table $3 \mathrm{CF}$ and PLI classification metals.

\begin{tabular}{|c|c|}
\hline CF & Classification \\
\hline 0 & None \\
\hline 1 & None to medium \\
\hline 2 & Moderate \\
\hline 3 & Moderate to strong \\
\hline 4 & Strongly polluted \\
\hline 5 & Strong to very strong \\
\hline 6 & Very strong \\
\hline PLI & Classification \\
\hline$>1$ & Polluted \\
\hline$<$ & Less polluted and/ or no pollution \\
\hline
\end{tabular}

Table 4 Metals concentration in sediment samples of Terengganu rivers

\begin{tabular}{|c|c|c|c|c|c|c|c|}
\hline \multirow{2}{*}{ Station } & \multicolumn{7}{|c|}{ Elements (mg/kg) } \\
\hline & $\mathrm{Cr}$ & $\mathrm{Cu}$ & $\mathbf{M g}$ & $\mathrm{K}$ & Mn & $\mathrm{Zn}$ & $\mathrm{Cl}$ \\
\hline SK 1 & 1.12 & 0.71 & 2769.00 & 247.33 & 7.58 & 3.03 & 398.00 \\
\hline SK 2 & 0.63 & 2.06 & 2233.30 & 280.23 & 5.30 & 3.08 & 485.00 \\
\hline SK 3 & 0.79 & 0.75 & 1857.10 & 143.16 & 10.34 & 3.77 & 530.00 \\
\hline SP 1 & 0.70 & 0.38 & 320.90 & 72.44 & 10.22 & 2.05 & 245.00 \\
\hline SP 2 & 0.67 & 0.73 & 355.13 & 146.10 & 4.27 & 3.16 & 360.00 \\
\hline SP 3 & 0.48 & 0.45 & 628.13 & 63.36 & 6.62 & 2.28 & 202.00 \\
\hline SD 1 & 12.80 & 13.28 & 458.00 & 1050.00 & 15.70 & 28.80 & 545.00 \\
\hline SD 2 & 12.50 & 15.04 & 492.00 & 1320.00 & 10.70 & 30.80 & 413.00 \\
\hline SD 3 & 12.40 & 15.20 & 440.00 & 1730.00 & 29.20 & 31.30 & 364.00 \\
\hline ST 1 & 1.02 & 4.48 & 222.00 & 790.00 & 16.40 & 11.20 & 389.00 \\
\hline ST 2 & 1.08 & 4.04 & 202.00 & 988.00 & 14.60 & 10.50 & 571.00 \\
\hline ST 3 & 0.82 & 3.98 & 230.00 & 774.00 & 23.80 & 11.58 & 141.00 \\
\hline SB 1 & 0.54 & 6.58 & 258.00 & 922.00 & 30.40 & 15.80 & 584.00 \\
\hline SB 2 & 0.62 & 6.00 & 264.00 & 950.00 & 20.40 & 16.40 & 583.00 \\
\hline SB 3 & 0.48 & 6.24 & 234.00 & 1270.00 & 33.70 & 14.60 & 168.00 \\
\hline Min & 0.48 & 0.38 & 202.00 & 63.36 & 4.27 & 2.05 & 141.00 \\
\hline Max & 12.80 & 15.20 & 2769.00 & 1730.00 & 33.70 & 31.30 & 584.00 \\
\hline Mean & 3.11 & 5.33 & 730.90 & 716.44 & 15.95 & 12.56 & 398.53 \\
\hline
\end{tabular}

*SK= Sungai Kerteh; SP= Sungai Paka; SD= Sungai Dungun; ST= Sungai Terengganu; SB= Sungai Besut.

\section{Assessment of metal pollution}

The enrichment factor assessment is the best parameter to predict the origin of the metals (Pekey, 2006). The EF values obtained from this study was shown in Table 6. The mean of EF value was indicated in decrease order; $\mathrm{Cl}(35)>\mathrm{Zn} \mathrm{(23)}>\mathrm{Cu}$ (10) $>\mathrm{Cr}, \mathrm{K}(2)>\mathrm{Mg}, \mathrm{Mn}$ (1). If the EF values more than 1, it indicate that metal concentration from the anthropogenic sources and $\mathrm{EF}$ value below that 1 is from natural sources (Parizanganeh et al., 2012). In this study, show most of the selected metals from sampling location are from the anthropogenic sources except SK 2, SP 1, SP 2, SP 3, SB 1, SB 2 , SB 3 for Cr metal, ST 1, St 2, ST 3, SB 1, SB 2, SB 3 for Mg metal, SK 3, SP 1, SP 2, SP 3 for K metal and SK 1, SK 2, SP 2, SP 3, SD 2 for Mn metal. 
Table 5 Comparison between present study and Malaysia previous study $(\mathrm{mg} / \mathrm{kg})$.

\begin{tabular}{cccccccccccc}
\hline Number & Area & $\mathbf{C r}$ & $\mathbf{C u}$ & $\mathbf{M g}$ & $\mathbf{K}$ & $\mathbf{M n}$ & $\mathbf{Z n}$ & $\mathbf{C l}$ & $\mathbf{R e f e r e n c e}$ \\
\hline 1 & Present study (average) & 3.11 & 5.33 & 730.9 & 716.44 & 15.95 & 12.56 & 398.53 & Present study \\
2 & Terengganu River Basin & 225.41 & 15.01 & 0.179 & 1.484 & 363.73 & 71.27 & na & Sultan et al., 2010 \\
3 & Hydroelectric reservoir, & 24.55 & na & 527.69 & 842.07 & 273.86 & 16.48 & na & Sim et al., 2014 \\
4 & Sarawak & Sungai Sedili Kecil, Johor & na & 26.3 & na & na & 190.5 & 55.1 & na & Shuhaimi-Othman et \\
5 & Baleh River, Sarawak & 75.45 & 34.59 & na & na & 793 & 70.64 & na & Sim et al., 2016 \\
6 & EEZ of the east coast of & na & 17.48 & na & na & 273.42 & 63.01 & na & Shaari et al., 2015 \\
7 & Peninsular Malaysia & Balok River, Pahang & 41.9 & 24.2 & na & na & 155.7 & na & 152.1 & Abdullah et al., 2015 \\
8 & Pinang River, Penang & na & 21.3 & na & na & 142 & 131 & na & Ong et al., 2015 \\
9 & West Port, Malaysia & $11.5-$ & $7.4-27.6$ & na & na & na & $23.4-$ & na & Sany et al., 2011 \\
\hline
\end{tabular}

Table 6 Enrichment Factor (EF) value in all sampling stations of selected Terengganu rivers.

\begin{tabular}{|c|c|c|c|c|c|c|c|}
\hline \multirow{2}{*}{ Station } & \multicolumn{7}{|c|}{ Enrichment Factor (EF) value } \\
\hline & $\mathrm{Cr}$ & $\mathrm{Cu}$ & $\mathrm{Mg}$ & K & Mn & $\mathrm{Zn}$ & Cl \\
\hline SK 1 & 1 & 2 & 5 & 1 & 0 & 7 & 39 \\
\hline SK 2 & 0 & 5 & 4 & 1 & 0 & 6 & 45 \\
\hline SK 3 & 1 & 2 & 3 & 0 & 1 & 9 & 53 \\
\hline SP 1 & 0 & 1 & 1 & 0 & 1 & 4 & 22 \\
\hline SP 2 & 0 & 2 & 1 & 0 & 0 & 7 & 33 \\
\hline SP 3 & 0 & 1 & 1 & 0 & 0 & 5 & 18 \\
\hline SD 1 & 7 & 28 & 1 & 2 & 1 & 54 & 45 \\
\hline SD 2 & 6 & 27 & 1 & 2 & 0 & 49 & 29 \\
\hline SD 3 & 7 & 30 & 1 & 4 & 1 & 55 & 28 \\
\hline ST 1 & 1 & 10 & 0 & 2 & 1 & 21 & 32 \\
\hline ST 2 & 1 & 10 & 0 & 3 & 1 & 23 & 55 \\
\hline ST 3 & 1 & 9 & 0 & 2 & 1 & 24 & 13 \\
\hline SB 1 & 0 & 13 & 0 & 2 & 2 & 28 & 45 \\
\hline SB 2 & 0 & 13 & 0 & 2 & 1 & 33 & 51 \\
\hline SB 3 & 0 & 13 & 0 & 3 & 2 & 28 & 14 \\
\hline Min & 0 & 1 & 0 & 0 & 0 & 4 & 13 \\
\hline Max & 7 & 10 & 5 & 2 & 2 & 23 & 55 \\
\hline Mean & 2 & 10 & 1 & 2 & 1 & 23 & 35 \\
\hline
\end{tabular}

Table 7 Contamination factor (CF) and pollution load index (PLI) values in sampling stations of selected Terengganu rivers.

\begin{tabular}{|c|c|c|c|c|c|c|c|c|}
\hline \multirow{2}{*}{ Station } & \multicolumn{7}{|c|}{ Contamination Index (CF) } & \multirow{2}{*}{ Pollution Load Index (PLI) } \\
\hline & $\mathrm{Cr}$ & $\mathrm{Cu}$ & Mg & $\mathbf{K}$ & Mn & $\mathbf{Z n}$ & $\mathbf{C l}$ & \\
\hline SK 1 & 0.01 & 0.03 & 0.13 & 0.01 & 0.01 & 0.05 & 0.84 & 0.04 \\
\hline SK 2 & 0.01 & 0.08 & 0.10 & 0.01 & 0.01 & 0.05 & 1.03 & 0.04 \\
\hline SK 3 & 0.01 & 0.03 & 0.08 & 0.01 & 0.01 & 0.06 & 1.12 & 0.04 \\
\hline SP 1 & 0.01 & 0.02 & 0.01 & 0.00 & 0.01 & 0.03 & 0.52 & 0.02 \\
\hline SP 2 & 0.01 & 0.03 & 0.02 & 0.01 & 0.01 & 0.05 & 0.76 & 0.02 \\
\hline SP 3 & 0.00 & 0.02 & 0.03 & 0.00 & 0.01 & 0.04 & 0.43 & 0.02 \\
\hline SD 1 & 0.10 & 0.53 & 0.02 & 0.05 & 0.02 & 0.44 & 1.15 & 0.13 \\
\hline SD 2 & 0.10 & 0.60 & 0.02 & 0.06 & 0.01 & 0.47 & 0.88 & 0.13 \\
\hline SD 3 & 0.10 & 0.61 & 0.02 & 0.08 & 0.04 & 0.48 & 0.77 & 0.15 \\
\hline ST 1 & 0.01 & 0.18 & 0.01 & 0.04 & 0.02 & 0.17 & 0.82 & 0.06 \\
\hline ST 2 & 0.01 & 0.16 & 0.01 & 0.05 & 0.02 & 0.16 & 1.21 & 0.06 \\
\hline ST 3 & 0.01 & 0.16 & 0.01 & 0.04 & 0.03 & 0.18 & 0.30 & 0.05 \\
\hline SB 1 & 0.00 & 0.26 & 0.01 & 0.04 & 0.04 & 0.24 & 1.24 & 0.07 \\
\hline SB 2 & 0.00 & 0.24 & 0.01 & 0.04 & 0.03 & 0.25 & 1.24 & 0.07 \\
\hline SB 3 & 0.00 & 0.25 & 0.01 & 0.06 & 0.05 & 0.22 & 0.36 & 0.06 \\
\hline Average & 0.02 & 0.21 & 0.03 & 0.03 & 0.02 & 0.19 & 0.84 & 0.08 \\
\hline
\end{tabular}

In general, $\mathrm{Cl}$ and $\mathrm{Zn}$ metals have recorded very high enriched in sediment samples but moderate to significant enrichment for $\mathrm{Cu}, \mathrm{Cr}$ and $\mathrm{K}$ metals. Meanwhile $\mathrm{Mg}$ and $\mathrm{Mn}$ metals were deficienct enriched in all sediment samples. The EF values indicates that all selected metals were evenly deposited throughout the sampling areas except metals $\mathrm{Cl}$ and $\mathrm{Zn}$ which have been recorded having highest enrichment at Sungai Dungun (SD 1) and Sungai Kerteh (SK 3). The position of SD 1 at the jetty with accommodated with the boat repair influence the higher enrichment at this particular area. Same goes with SK 3 that near with petroleum plantation. The moderate to significant enrichment of $\mathrm{Cu}, \mathrm{Cr}$ and $\mathrm{K}$ metals might be related with residential and a fisheries area that was release throughout treated and untreated discharge to the rivers.

From this study, Pollution Load Index (PLI) in all sampling stations shows below 1 that indicated less pollution (Table 7). The mean of $\mathrm{CF}$ values for the selected metals in study areas follow the decreasing order as $\mathrm{Cl}<\mathrm{Cu}<\mathrm{Zn}<\mathrm{Mg}, \mathrm{K}<\mathrm{Mn}$, Cr. As similar with 
$\mathrm{EF}$ value, $\mathrm{Cl}$ metals is the highest metal than other metals and it proven that the sources of pollution comes from the anthropogenic activities

\section{CONCLUSION}

All the selected studied metals which are $\mathrm{Cr}, \mathrm{Cu}, \mathrm{Mg}, \mathrm{K}, \mathrm{Mn}, \mathrm{Zn}$ and $\mathrm{Cl}$ from five different rivers in Terengganu indicated less pollution in all sampling stations that proved with their PLI below than 1. Althought the PLI value in all sampling stations shown below than 1 but due to the rapid development in Terengganu rivers, the prevention must take action in order to minimize the metal contamination in sediment. The analysis of Terengganu rivers also shown, the potential pollution comes from the antropogenic activities from nearby area of sampling station and was proven with EF value. The data from this study will be useful for environmental management at Terengganu Rivers and also as baseline date for the future research particularly in Terengganu river.

\section{ACKNOWLEDGEMENT}

The authors would like special thanks to Malaysian Ministry of Higher Education for financial supports under R/RAGS/A08.00/01203A/001/2015/000187 grant and also to Faculty of Earth Sciences (Jeli Campus), Universiti Malaysia Kelantan for providing kindly laboratory and material supports. And also to Instituate of Ocean \& Earth Sciences, University of Malaya for hospitality throughout the sampling for this research.

\section{REFERENCES}

Adamo, P., Arienzo, M., Imperato, M., Naimo, D., Nardi, G., Stanzione, D. 2005. Distribution and partition of heavy metals in surface and sub-surface sediments of Naples City Port. Chemosphere, 61, 6, 800-809.

Alkarkhi, A. F., Ismail, N., Ahmed, A., Mat Easa, A. 2009. Analysis of heavy metal concentrations in sediments of selected estuaries of malaysia-a statistical assessment. Environmental monitoring and assessment, 153, 1-4, 179.

Aprile, F., Bouvy, M. 2008. Distribution and enrichment of heavy metals at the Tapacurá River Basin, Northeastern Brazil. Brazilian Journal of Aquatic Science and Technology, 12, 1, 1-8.

Barakat, A., El Baghdadi, M., Rais, J., Nadem, S. 2012. Assessment of heavy metal in surface sediments of day river at Beni-mellal region, Morocco. Research Journal of Environmental and Earth Sciences, 4, 8, 797-806.
Hangsleben, M., Suh, D. 2006. Sediment pollution. TSM 242 Semester Project.

Hasrizal, S., Kamaruzzaman, B., Sakri, I., Ong, M. C., Azhar, M. 2009. Seasonal distribution of organic carbon in the surface sediments of the Terengganu nearshore coastal area Americam Journal of Environmental Sciences, 5(1), 111-115.

Likuku, A. S., Mmolawa, K. B., Gaboutloeloe, G. K. 2013. Assessment of heavy metal enrichment and degree of contamination around the coppernickel mine in the Selebi Phikwe region, Eastern Botswana. Environment and Ecology Research, 1, 2, 32-40.

MMD. 2016. Monthly rainfall in East Coast of Peninsular Malaysia 2016. Retrieved Malaysian Metrological Department (MMD)

Parizanganeh, A. H., Bijnavand, V., Zamani, A. A., Hajabolfath, A. 2012. Concentration, distribution and comparison of total and bioavailable heavy metals in top soils of Bonab District in Zanjan province. Open Journal of Soil Science, 2, 02, 123.

Qingjie, G., Jun, D., Yunchuan, X., Qingfei, W., Liqiang, Y. 2008. Calculating pollution indices by heavy metals in ecological geochemistry assessment and a case study in parks of Beijing. Journal of China University of Geosciences, 19, 3, 230-241.

Rajan, S., Firdaus, N. N. M., Appukutty, M., Ramasamy, K. 2012. Effects of climate changes on dissolved heavy metal concentrations among recreational park tributaries in Pahang, Malaysia. Biomedical Research, 23, 1.

Rajeswari, T. R., Sailaja, N. 2014. Impact of heavy metals on environmental pollution. Journal of Chemical and Pharmaceutical Sciences, 3, 175-181.

Ren, J., Shang, Z., Tao, L., Wang, X. 2015. Multivariate analysis and heavy metals pollution evaluation in Yellow River surface sediments. Polish Journal of Environmental Studies, 24, 3.

Sultan, K., Shazili, N. A. 2010. Geochemical baselines of major, minor and trace elements in the tropical sediments of the Terengganu River Basin, Malaysia. International Journal of Sediment Research, 25, 4, 340-354.

Suratman, S., Sailan, M., Hee, Y., Bedurus, E., Latif, M. T. 2015. A preliminary study of water quality index in Terengganu River Basin, Malaysia. Sains Malaysiana, 44, 1, 67-73.

Szalinska, E., Drouillard, K. G., Fryer, B., Haffner, G. D. 2006. Distribution of heavy metals in sediments of the Detroit River. Journal of Great Lakes Research, 32, 3, 442-454.

Tomlinson, D., Wilson, J., Harris, C., Jeffrey, D. 1980. Problems in the assessment of heavy-metal levels in estuaries and the formation of a pollution index. Helgoländer meeresuntersuchungen, 33, 1, 566.

Yang, L., Zhu, L., Liu, Z. 2011. Occurrence and partition of perfluorinated compounds in water and sediment from Liao River and Taihu Lake, China. Chemosphere, 83, 6, 806-814.

Zulkifli, S. Z., Mohamat-Yusuff, F., Ismail, A., Aziz, A., Sabuti, A. A., Mohamed, C. A. R. 2015. Status of heavy metals in surface sediments of the Western part of the Johor Straits using a sediment quality guideline. World, 7, 3, 214-220. 